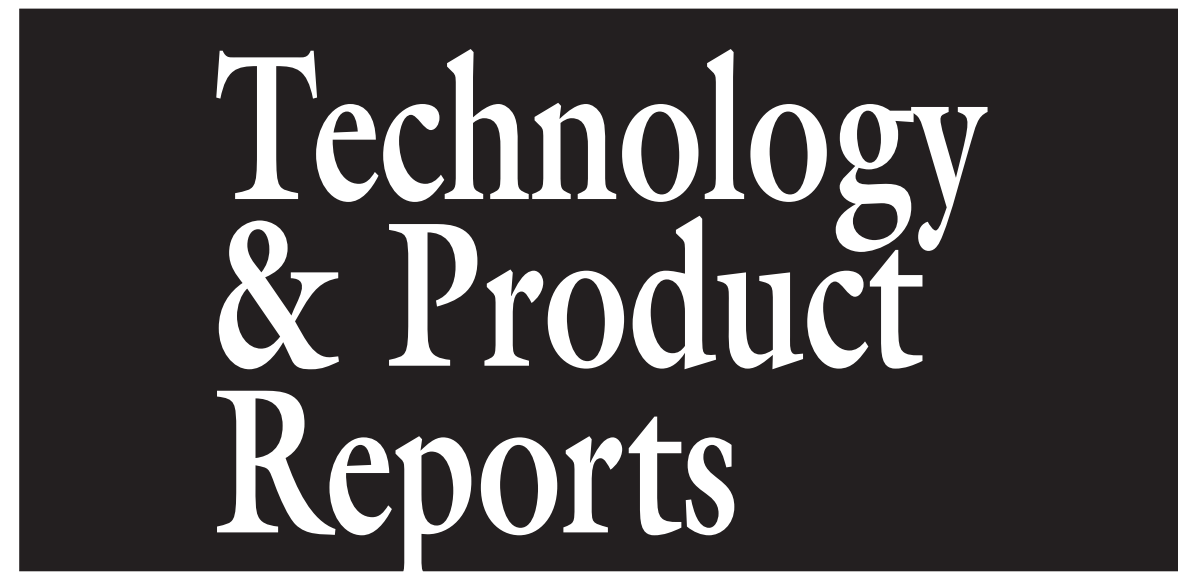

\section{Apple Scab Management Assisted by Postharvest Tree Defoliation with Vegetable Oil Emulsion}

\author{
Eric Curry ${ }^{1}$, Zhiguo Ju ${ }^{1}$, and Yousheng Duan ${ }^{2}$
}

\begin{abstract}
AdDitional INDEX wORDs. abscission, Malus, orchard management, organic, Venturia inaequalis

Summary. Vegetable oil emulsion (VOE) was applied to 'Gala' and 'Fuji' apple (Malus $\times$ domestica) trees after harvest to hasten defoliation and reduce apple scab (Venturia inaequalis). Applied at $2 \%, 4 \%$, or $6 \%$, VOE applied to whole trees in the fall induced leaf drop, with the highest concentration causing the most defoliation. At the same concentration, VOE applied in early, mid, or late October had similar effects on leaf drop. VOE treatment reduced respiration and stimulated ethylene production in shoot tissue within 24 hours of application. None of the treatments affected tree hardiness during the winter, or shoot growth the following spring. Return bloom density was unaffected; however, VOE tended to delay anthesis by 2 to $\mathbf{5}$ days. Under controlled conditions, 'Gala' and 'Fuji' trees inoculated with scab spores developed $48 \%$ and $65 \% \mathrm{scab}$, respectively. VOE-induced defoliation reduced scab by $50 \%$ to $65 \%$. VOE-induced defoliation plus manual leaf removal from the orchard floor, or VOE-induced defoliation in late fall (15 Oct.-15 Nov.) plus application of 5\% lime sulfur in early spring, controlled scab to $<5 \%$ on both leaves and fruit. Neither lime sulfur nor urea applied in late fall at $2 \%$ induced defoliation or controlled scab. VOE at $4 \%$ plus $2 \%$ lime sulfur and/or $2 \%$ urea applied in late fall, however, defoliated 'Gala' trees effectively and controlled scab on fruit to $<7 \%$ the following spring. In the 'Fuji' planting, the combination of $4 \%$ VOE plus $2 \%$ lime sulfur and $2 \%$ urea reduced scab on fruit from $21 \%$ in controls to $0 \%$.
\end{abstract}

A pple scab is a widespread disease of apple and ornamental crabapple (Malus spp.) (Biggs, 1990; MacHardy, 1996). Without adequate control, it may greatly reduce marketable yield by causing extensive

${ }^{1}$ U.S. Department of Agriculture, Agriculture Research Service, Tree Fruit Research Laboratory, 1104 N. Western Ave., Wenatchee, WA 98801

${ }^{2}$ Zibo Zichuan Pingguo, Zengseji Chang, Shandong, China.

Mention of a trademark, proprietary product or vendor does not constitute a guarantee or warranty of the product by the U.S. Dept. of Agriculture and does not imply its approval to the exclusion of other products or vendors that also may be suitable. damage to fruit, especially in regions where spring weather is cool and humid. In addition to economic loss from reduced fruit quality, scab can be both time-consuming and costly to control.

The scab fungus overwinters on fallen leaves on the orchard floor. During this time, the mycelia penetrate the leaves and form pseudothecia, which normally survive through the winter (Biggs, 1990; MacHardy, 1996). Because this overwintering stage occurs mainly on fallen leaves, reasonably, scab infection the following season could be reduced by removing infected leaves from the orchard floor. In China, removing fallen leaves from the orchard floor in late fall and/or early winter is an effective scab management tool. Some tree cultivars, as well as some trees within a block of similar trees, shed leaves gradually from late fall to early winter. Others, in contrast, shed very few leaves even in early winter, due mainly to secondary growth in the fall. Thus, repeated cleaning of the entire orchard floor is required. Although successful, this practice may have limited usefulness in certain countries because the cost of labor is prohibitively high.

In our preliminary investigations, we found high concentrations of VOE induced drop of both leaves and fruit from apple trees when applied before fruit harvest (unpublished data). Based on this observation, we proposed that defoliating trees after harvest in November might facilitate management of fallen leaves in commercial orchards.

Lime sulfur has been used to control many diseases including apple scab (Vossen and Gubler, 1995). The application of lime sulfur to apple trees in humid areas during the growing season, however, has caused fruit marking, particularly from russetting (McArtney, et al., 2000; Vossen and Gubler, 1995). To avoid phytotoxicity, it would be beneficial to determine if lime sulfur could be applied instead in November to either kill the pathogens or reduce inoculation the following spring. The effects of combinations of lime sulfur

\begin{tabular}{llll}
\hline $\begin{array}{l}\text { Units } \\
\begin{array}{l}\text { To convert U.S. to SI, } \\
\text { multiply by }\end{array}\end{array}$ & U.S. unit & SI unit & $\begin{array}{l}\text { To convert SI to U.S., } \\
\text { multiply by }\end{array}$ \\
\hline 0.4047 & acre $(\mathrm{s})$ & $\mathrm{ha}$ & 2.4711 \\
29.5735 & $\mathrm{fl} \mathrm{oz}$ & $\mathrm{mL}$ & 0.0338 \\
0.3048 & $\mathrm{ft}$ & $\mathrm{m}$ & 3.2808 \\
9.3540 & gal/acre & $\mathrm{L} \cdot \mathrm{ha}^{-1}$ & 0.1069 \\
2.5400 & inch $(\mathrm{es})$ & $\mathrm{cm}$ & 0.3937 \\
25.4000 & inch $(\mathrm{es})$ & $\mathrm{mm}$ & 0.0394 \\
1 & $\mathrm{ppm}$ & $\mathrm{mg} \cdot \mathrm{L}^{-1}$ & 1 \\
$\left({ }^{\circ} \mathrm{F}-32\right) \div 1.8$ & ${ }^{\circ} \mathrm{F}$ & ${ }^{\circ} \mathrm{C}$ & $\left(1.8 \times{ }^{\circ} \mathrm{C}\right)+32$
\end{tabular}


and VOE applied in late fall on scab control have not been investigated.

Urea applied after harvest but before leaf fall, or in early spring, has been shown to reduce the number of ascospores as well as scab severity on apples (Burchill, 1968; Carisse et al., 2000; Sutton et al., 2000). Although fall applications have been more effective in this respect (Sutton et al., 2000), they have not been widely adopted by growers because high concentrations of urea at this time may result in nitrogen accumulation in buds, thereby stimulating regrowth and increasing the possibility of winter injury in certain conditions (Sutton et al., 2000). Since trees treated with a high concentration of VOE defoliated within a few days, we proposed a possible solution might include combining VOE for tree defoliation and urea to accelerate leaf decomposition, thereby reducing ascospore population and scab development the following spring without negatively affecting tree hardiness.

Objectives in this study were to 1) determine near optimum concentration and time of application of VOE for defoliating apple trees; 2 ) investigate the effects of VOE treatment on shoot respiration, shoot hardiness, fruit bud hardiness, and shoot growth; 3 ) evaluate the efficacy of VOE-induced defoliation plus leaf removal from the orchard floor for scab control; and 4) explore combinations of VOE plus urea or lime sulfur as a single postharvest foliar treatment for controlling scab.

\section{Materials and methods}

Plant material and treatMENTS. The first experiment was conducted in 1999 to evaluate VOE for defoliation and determine if certain tree physiological processes were affected. Trees used in this trial were located near Zibo City in Shandong province, China, and were in their sixth-leaf (sixth growing season after grafting) on Malling 111 (M.111) rootstock planted in 1992. Emulsion concentrate containing 60\% stripped corn oil $(\alpha$-tocopherol reduced to $<5$ $\mathrm{mg} \cdot \mathrm{L}^{-1}$; Aldrich, Milwaukee, Wis.) was made by mixing six parts corn oil, one part Tween 60 , and three parts hot water $\left(90{ }^{\circ} \mathrm{C}\right)$ with continuous stirring (Ju and Curry, 2000; Ju et al., 2000 ). VOE treatments prepared by appropriately diluting the concentrate with water were applied to whole trees to the point of runoff $\left(\sim 400 \mathrm{~L} \cdot \mathrm{ha}^{-1}\right)$ with a handgun sprayer at $2 \%, 4 \%$, or $6 \%$ on 1,15 , or 30 Oct., respectively. Untreated trees served as controls. In the same experiment, $2 \%$ lime sulfur or urea was applied to different trees on the same dates. Within each of three 'Gala' and 'Fuji' orchards, treatments were arranged in a randomized complete-block design with six replications of four trees. On each tree, two scaffold limbs were selected and labeled for later evaluation. Leaf drop, measured by counting all the leaves beneath the tree, was recorded daily at the same time each morning; respiration and ethylene production from current season shoot tissue was measured every day for $7 \mathrm{~d}$ after VOE application. Injury to shoots and flower buds was assessed by counting the number of dead shoots and blossom clusters the following spring, recording the date of full bloom, and measuring the total shoot growth the following season after growth cessation.

In the second experiment, we evaluated the effects on scab incidence of treating with combinations of VOE, lime sulfur, and leaf removal from the orchard floor. Individual third-leaf 'Gala' and 'Fuji' trees from the nursery were planted $0.5 \times 0.5 \mathrm{~m}$ within small plastic enclosures to prevent spore contamination among treatments. High scab pressure was achieved by inoculating trees with scab spores beginning in early spring and continuing throughout the 1999 growing season without fungicide treatment. In Fall 1999, trees received the following treatments: 1) VOE at $4 \%$ applied on 15 Oct. ('Gala') or 30 Oct. ('Fuji') plus leaves on orchard floor removed by hand raking $5 \mathrm{~d}$ later; 2) VOE at $4 \%$ applied on 15 Oct. ('Gala') or 30 Oct. ('Fuji') without leaf removal from the orchard floor; 3) VOE at 4\% applied on 15 Oct. ('Gala') or 30 Oct. ('Fuji') without leaf removal, plus lime sulfur at $5 \%$ sprayed on 20 Mar. 2000; and 4) untreated controls. Treatments were applied in a randomized completeblock design to three trees in each of three replications. Leaf drop was measured $7 \mathrm{~d}$ after VOE application. Tree hardiness (dead shoots) and shoot growth were evaluated the following season. Scab severity was evaluated 30 June 2000.

A third experiment was conducted in 2000 to investigate approaches that could be used to control scab with VOE without further leaf treatment. 'Gala' and 'Fuji' trees used were similar to those described in the second experiment. Treatments included: 1) VOE at $4 \% ; 2$ ) lime sulfur at $2 \% ; 3$ ) urea at $2 \%$; 4) VOE at $4 \%$ plus $2 \%$ lime sulfur; 5 ) VOE at $4 \%$ plus $2 \%$ urea; and 6 ) VOE at $4 \%$ plus $2 \%$ lime sulfur and $2 \%$ urea. 'Gala' trees were treated on 15 Oct. and 'Fuji' on 30 Oct. Untreated trees within each block served as controls. A treatment consisted of three replications, each with three trees. Leaf drop was measured $7 \mathrm{~d}$ after VOE application. Tree hardiness (dead shoots) and shoot growth were evaluated the following season. Scab severity was evaluated on 30 June 2001 by counting the number of lesions on 100 leaves, and all of the fruit, per tree and was reported as percentage of whole leaves or fruits infected.

The fourth experiment was conducted in 2000 in four 7- to 12-yearold commercial 'Fuji' orchards with a history of high scab incidence during the growing season. Isolated orchards about 0.5 ha in area were selected to reduce the possibility of spore contamination from adjacent treatments. Orchards were divided into three blocks, each of which received one of the following treatment regimes: 1 ) untreated; 2) captan; and 3) 4\% VOE plus $2 \%$ lime sulfur and $2 \%$ urea. The captan treatment (six applications at $1.1 \mathrm{~kg} \cdot \mathrm{ha}^{-1}$ ) was located in the middle block to separate the control and the treatment of VOE plus lime sulfur plus urea that was applied 30 Oct. To reduce spore contamination, a 2 -m plastic wall was installed along the border of the different treatments from September to June, and trees adjacent to the border were not included in subsequent evaluations. Tree hardiness (dead shoots), blossom density, bloom date, and shoot growth were evaluated the following year. Scab severity was evaluated on 1 June. The same experiment was repeated in 2001 with the same design using four different orchards.

MEASUREMENT OF RESPIRATION AND ETHYLENE PRODUCTION. After VOE treatment, five l-year-old shoots were randomly collected from each tree. The shoots were cut into $25-\mathrm{mm}$ sections, weighed, and placed into a septum-capped 100-mL test tube containing $10 \mathrm{~mL}$ of distilled water. After $\mathrm{l}$ h at $20^{\circ} \mathrm{C}$, a 5 -mL air sample was taken from the test tube with a syringe and used for respiration and ethylene measurement with gas chromatogra- 
phy (Hewlett-Packard Model 5890A; Agilent Technologies, Palo Alto, Calif.). Carbon dioxide and oxygen were analyzed with a $30 \mathrm{~m} \times 0.53-\mathrm{mm}$ i.d. polystyrene (GSQ) column (J \&W Scientific, Folsom, Calif.) equipped with a thermal conductivity detector. Column and detector temperatures were 40 and $120^{\circ} \mathrm{C}$, respectively, and the $\mathrm{He}$ flow rate was $4.8 \mathrm{~mL} \cdot \mathrm{min}^{-1}$. Ethylene was measured using a glass column $(610$ $\times 3.2 \mathrm{~mm}$ i.d.) packed with Porapak Q (J \& W Scientific) (90-100 mesh). Oven, injector, and FID temperatures were 50,50 and $200{ }^{\circ} \mathrm{C}$, respectively. Gas flows for nitrogen, hydrogen, and air were 30,30 , and $300 \mathrm{~mL} \cdot \mathrm{min}^{-1}$, respectively.

EVALUATION OF TREE HARDINESS, RETURN BLOOM, AND SHOOT GROWTH. Susceptibility to winter injury (tree hardiness) was evaluated by counting the number of dead 1-year-old shoots in spring. Bloom dates and the number of blossoms on each labeled scaffold limb were recorded in the spring. Current season shoot growth was evaluated by measuring the length of new shoots on each labeled scaffold after cessation of new growth.

Statistical analysis. Statistics were performed using SAS (SAS Institute, Cary, N.C.). Normally distributed data were subjected to analysis of variance and means were separated using Tukey's studentized range test (Figs. $1-3)$. Data not normally distributed (Tables 1-3) were subjected to the Kruskal-Wallis test. Only results significant at $P \leq 0.05$ are discussed.

\section{Results}

EFFects of VOE ON DEFoliaTION OF APPLE TREES. Because data from both cultivars were similar, only figures from 'Fuji' apple trees are shown. Regardless of cultivar, VOE applied at $2 \%, 4 \%$, or $6 \%$ defoliated trees in a concentration-dependent manner (Fig. 1). VOE at $2 \%$ did not defoliate adequately after $7 \mathrm{~d}$, but at $\geq 4 \%$ VOE defoliated approximately $90 \%$ of leaves within $5 \mathrm{~d}$ after treatment. VOE applied at different times gave similar results on tree defoliation (Fig. 2). Interactions between time of application and concentration were nonsignificant. VOE did not affect tree hardiness $(<1.0$ dead twigs per treatment $)$, return bloom $($ mean $=65 \%)$, or growth of new shoots $($ mean $=47 \mathrm{~cm})$; however, it tended to delay anthesis by 2 to $5 \mathrm{~d}$ on 'Gala' and 'Fuji' apple

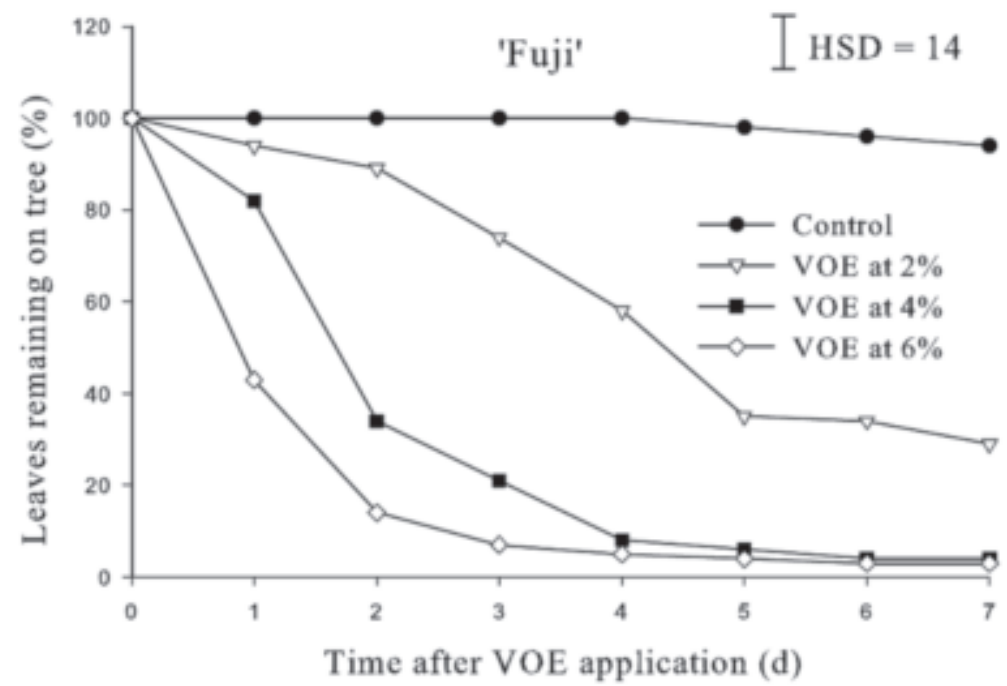

Fig. 1. Percentage of leaves remaining on the tree after treating with $2 \%, 4 \%$, or 6\% (v:v) vegetable oil emulsion (VOE) applied to 'Fuji' apple trees (30 Oct.). Bars represent the absolute difference between two sample means on any given day, required for significance at the $\mathbf{9 5 \%}$ confidence level using Tukey's honestly significant difference test (HSD).

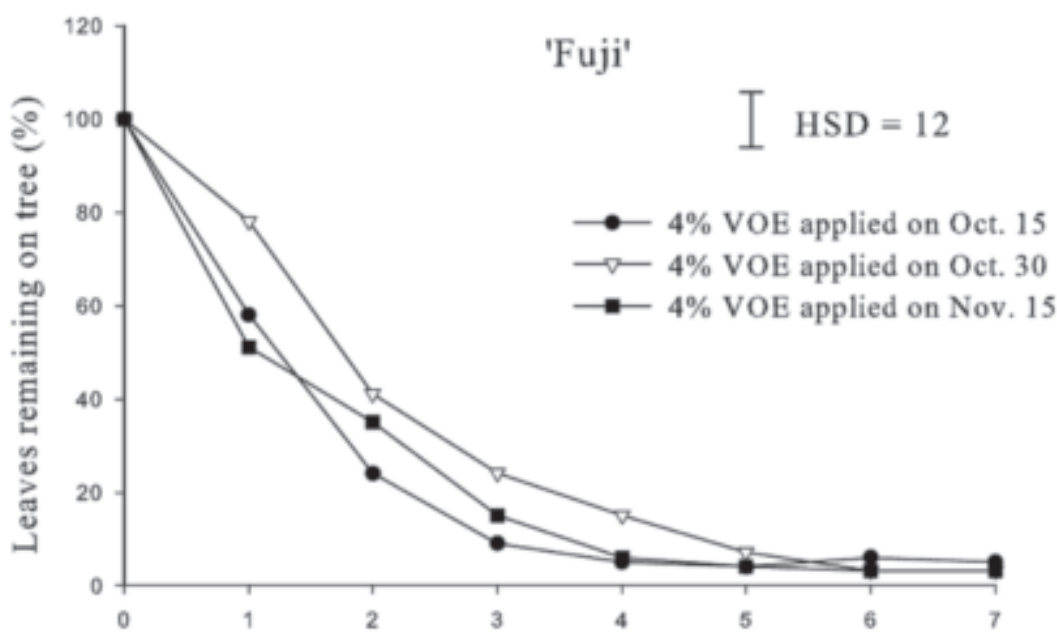

Time after VOE application (d)

Fig. 2. Percentage of leaves remaining on the tree after treating with $4 \%(\mathrm{v}: \mathrm{v})$ vegetable oil emulsion (VOE) applied on 15 Oct., 30 Oct. or 15 Nov. to 'Fuji' apple trees. Bars represent the absolute difference between two sample means on any given day, required for significance at the $95 \%$ confidence level using Tukey's honestly significant difference test (HSD).

trees with the higher concentration, resulting in greater delay the following spring (personal observation). Neither lime sulfur nor urea applied alone was effective in defoliating trees (data not shown).

EFFECTS OF VOE TREATMENT ON LEAF RESPIRATION AND ETHYLENE PRODUCTION. On both 'Gala' and 'Fuji' apple trees, VOE reduced respiration and stimulated ethylene production within $\mathrm{l} \mathrm{d}$ of application compared with controls (Fig. 3). The effects of treatment on respiration and ethylene production appeared concentrationdependent.

EFFECTS OF TREE DEFOLIATION PLUS LEAF TREATMENT ON SCAB CONTROL. Untreated controls of both cultivars developed a fairly high percentage of infection on leaves and fruit (Table 1). VOE defoliation without leaf removal from the orchard floor reduced scab by $83 \%$ to $87 \%$. Lime sulfur applied at $5 \%$ in early spring to trees treated the previous fall with VOE further 

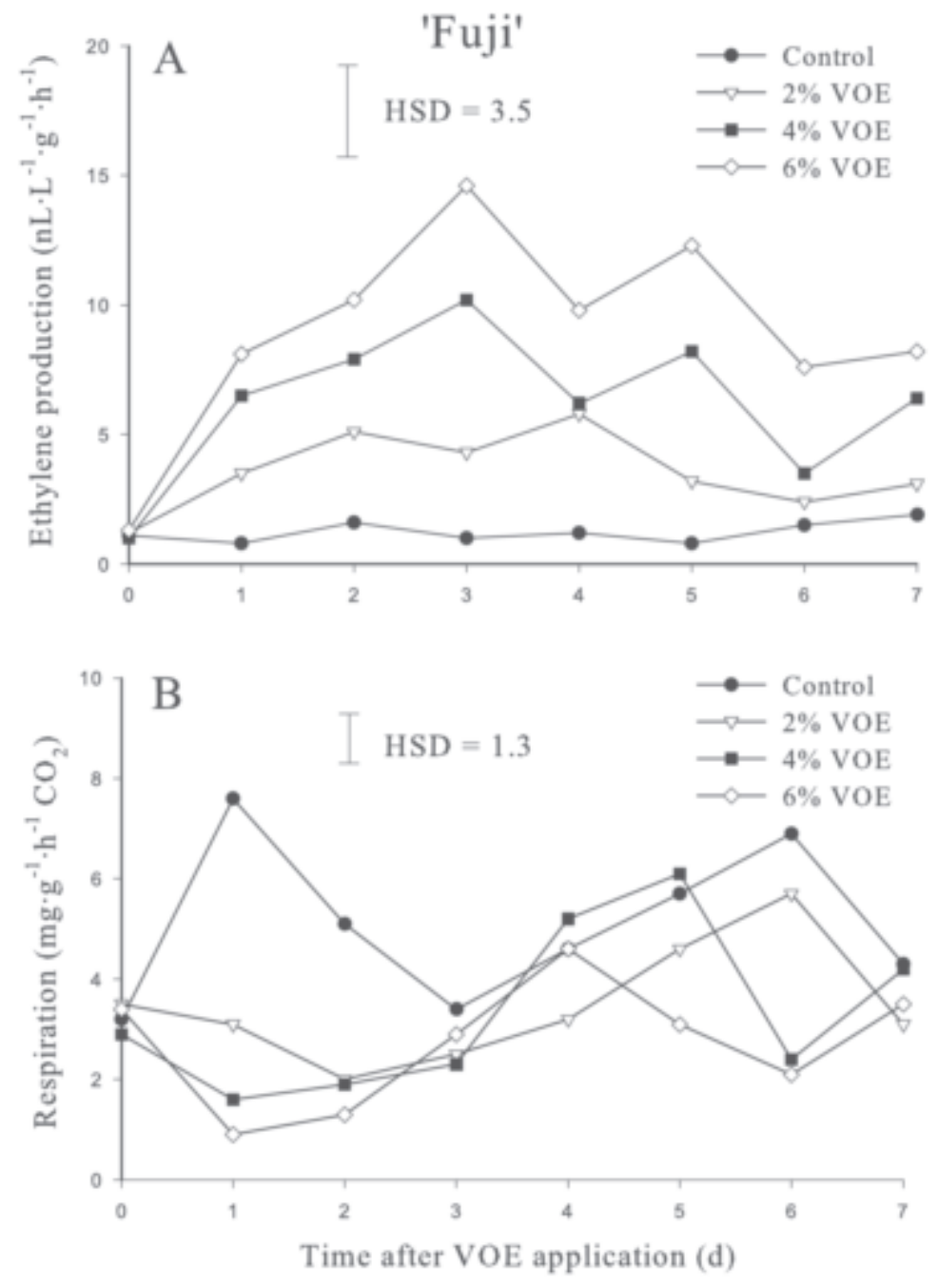

Fig. 3. Ethylene production (A) and respiration (B) of current season 'Fuji' apple tree shoot tissue excised immediately following treatment on 30 Oct. with $2 \%$, $4 \%$, or $6 \%$ (v:v) vegetable oil emulsion (VOE). Bars represent the absolute difference between two sample means on any given day, required for significance at the 95\% confidence level using Tukey's honestly significant difference test (HSD).

reduced levels of scab. VOE defoliation plus leaf removal from the orchard floor completely controlled scab. VOE treatment did not affect tree hardiness or shoot growth the following spring (data not shown).

EFFECTS OF TREE DEFOLIATION WITHOUT FURTHER LEAF TREATMENT ON SCAB CONTROL IN A CONTROLLED ENVIRONMENT. Tree defoliation with VOE in late fall reduced scab by about $50 \%$ on both cultivars (Table 2). Neither lime sulfur alone nor urea at $2 \%$ applied in late fall was effective in controlling scab. Compared to controls, urea delayed leaf drop by about 3 to $5 \mathrm{~d}$ (data not shown). VOE plus lime sulfur, or the combination of VOE plus both lime sulfur and urea, defoliated trees more quickly than VOE alone (data not shown) and controlled scab to a low level. VOE plus urea was similar to VOE plus lime sulfur in scab control in 2000 but was less effective in 2001 (data not shown).

EFFECTS OF THE COMBINATION OF VOE, LIME SULFUR, AND UREA ON SCAB CONTROL IN COMMERCIAL ORCHARDS. In isolated commercial orchards, $4 \%$ VOE plus $2 \%$ lime sulfur and $2 \%$ urea reduced scab on 'Fuji' trees from $28 \%$ in controls to $2 \%$ in 2000 , and from $35 \%$ to $1 \%$ in 2001 (Table 3). Scab level resulting from this treatment combination was similar to that obtained from the block receiving the captan applications ( $2 \%$ in 2000 and $1 \%$ in 2001$)$. The treatment combination did not affect tree hardiness, return bloom, or new shoot growth (data not shown), but delayed anthesis by 2 to $4 \mathrm{~d}$ (personal observation).
Table 1. Effects of tree defoliation by vegetable oil emulsion (VOE) plus leaf removal from the orchard floor or lime sulfur on scab control of 'Gala' and 'Fuji' apple trees under controlled conditions. ${ }^{\mathrm{z}}$

\begin{tabular}{|c|c|c|}
\hline Treatment & $\begin{array}{c}\text { Scab on } \\
\text { leaves }(\%)\end{array}$ & $\begin{array}{l}\text { Scab on } \\
\text { fruit }(\%)\end{array}$ \\
\hline \multicolumn{3}{|c|}{ Gala } \\
\hline Control & $48 \mathrm{a}^{\mathrm{y}}$ & $21 \mathrm{a}$ \\
\hline $4 \% \mathrm{VOE}$ & $17 \mathrm{~b}$ & $13 \mathrm{~b}$ \\
\hline $\begin{array}{l}4 \% \mathrm{VOE}+ \\
\text { leaf removal } \\
4 \% \mathrm{VOE}+\end{array}$ & $0 \mathrm{c}$ & $0 \mathrm{c}$ \\
\hline $5 \%$ lime sulfur & $4 \mathrm{c}$ & $3 \mathrm{c}$ \\
\hline \multicolumn{3}{|c|}{ Fuji } \\
\hline Control & $65 a$ & $27 \mathrm{a}$ \\
\hline $4 \% \mathrm{VOE}$ & $21 \mathrm{~b}$ & $16 \mathrm{~b}$ \\
\hline $\begin{array}{l}4 \% \mathrm{VOE}+ \\
\text { leaf removal } \\
4 \% \mathrm{VOE}+\end{array}$ & $0 \mathrm{c}$ & $0 \mathrm{c}$ \\
\hline $5 \%$ lime sulfur & $3 \mathrm{c}$ & $4 \mathrm{c}$ \\
\hline \multicolumn{3}{|c|}{$\begin{array}{l}{ }^{2} \mathrm{VOE}=\text { vegetable oil emulsion applied at } 4 \% \text { on } 15 \\
\text { Oct. ('Gala') and } 30 \text { Oct. ('Fuji') } 1999 \text {; leaf removal } \\
\text { = leaves were removed from the orchard floor by hand } \\
\text { labor } 5 \mathrm{~d} \text { after VOE application; lime sulfur = lime } \\
\text { sulfur at } 5 \% \text { was applied on } 20 \mathrm{Mar} \text {. } 2000 \text {. } \\
\text { "Mean separations in columns for a given cultivar by } \\
\text { Kruskal-Wallis test at } P \leq 0.05 \text {. }\end{array}$} \\
\hline
\end{tabular}

Table 2. Effects of vegetable oil emulsion (VOE), lime sulfur, urea, or combination treatments applied in late fall on scab control of 'Gala' or 'Fuji' apple trees under controlled conditions ${ }^{\mathrm{z}}$.

\begin{tabular}{|c|c|c|}
\hline Treatment & $\begin{array}{c}\text { Scab on } \\
\text { leaves }(\%)\end{array}$ & $\begin{array}{l}\text { Scab on } \\
\text { fruit }(\%)\end{array}$ \\
\hline \multicolumn{3}{|c|}{ Gala } \\
\hline Control & $33 a^{y}$ & $19 \mathrm{a}$ \\
\hline $4 \% \mathrm{VOE}$ & $21 \mathrm{~b}$ & $9 \mathrm{~b}$ \\
\hline $2 \%$ lime sulfur & 34 a & $22 \mathrm{a}$ \\
\hline $2 \%$ Urea & $39 a$ & $20 \mathrm{a}$ \\
\hline $4 \% \mathrm{VOE}+$ & & \\
\hline $2 \%$ lime sulfur & $6 c$ & $3 \mathrm{~b}$ \\
\hline $4 \%$ VOE + $2 \%$ urea & $9 \mathrm{c}$ & $5 \mathrm{~b}$ \\
\hline $\begin{array}{c}4 \% \text { VOE }+2 \% \text { lime } \\
\text { sulfur }+2 \% \text { urea }\end{array}$ & $1 \mathrm{c}$ & $1 \mathrm{~b}$ \\
\hline \multicolumn{3}{|c|}{ Fuji } \\
\hline Control & $49 \mathrm{a}$ & $21 \mathrm{a}$ \\
\hline $4 \% \mathrm{VOE}$ & $20 \mathrm{~b}$ & $7 \mathrm{~b}$ \\
\hline $2 \%$ lime sulfur & $43 a$ & $24 \mathrm{a}$ \\
\hline $2 \%$ urea & $45 \mathrm{a}$ & $18 \mathrm{a}$ \\
\hline $4 \% \mathrm{VOE}+$ & & \\
\hline $2 \%$ lime sulfur & $5 \mathrm{c}$ & $0 \mathrm{c}$ \\
\hline $4 \% \mathrm{VOE}+2 \%$ urea & $17 \mathrm{~b}$ & $9 \mathrm{~b}$ \\
\hline $\begin{array}{c}4 \% \text { VOE }+2 \% \text { lime } \\
\text { sulfur }+2 \% \text { urea }\end{array}$ & $2 \mathrm{c}$ & $0 \mathrm{c}$ \\
\hline
\end{tabular}

${ }^{2}$ Treatments were applied on 20 Oct. 2000 and evaluations made on 30 June 2001.

yean separations in columns for a given cultivar by Kruskal-Wallis test at $P \leq 0.05$. 
Table 3. Comparison of captan with a combination treatment of vegetable oil emulsion (VOE) plus lime sulfur and urea, applied in late fall on scab control of 'Fuji' apple trees ${ }^{\mathrm{z}}$.

\begin{tabular}{|c|c|c|}
\hline Treatment & $\begin{array}{c}\text { Scab on } \\
\text { leaves (\%) }\end{array}$ & $\begin{array}{l}\text { Scab on } \\
\text { fruit }(\%)\end{array}$ \\
\hline \multicolumn{3}{|c|}{2000} \\
\hline Control & $33 a^{y}$ & $19 a$ \\
\hline Captan & $1 \mathrm{~b}$ & $0 \mathrm{~b}$ \\
\hline $\begin{array}{l}4 \% \text { VOE }+2 \% \text { lime } \\
\text { sulfur }+2 \% \text { urea }\end{array}$ & $1 \mathrm{~b}$ & $\mathrm{lb}$ \\
\hline \multicolumn{3}{|c|}{2001} \\
\hline Control & $49 \mathrm{a}$ & $21 \mathrm{a}$ \\
\hline Captan & $2 \mathrm{~b}$ & $1 \mathrm{~b}$ \\
\hline $\begin{array}{l}4 \% \text { VOE }+2 \% \text { lime } \\
\text { sulfur }+2 \% \text { urea }\end{array}$ & $1 \mathrm{~b}$ & $1 \mathrm{~b}$ \\
\hline
\end{tabular}

${ }^{2}$ Treatments were applied in different orchards on 20 Oct. 2000 and 2001; scab was evaluated in June the year after treatment.

${ }^{y}$ Mean separation within columns and years by Kruskal-Wallis test at $P \leq 0.05$.

\section{Discussion}

Data indicate VOE is an effective postharvest defoliant on 'Gala' and 'Fuji' apple trees. The mechanism of VOE-induced leaf drop may be related to the concomitant suppression of respiration and stimulation of ethylene production (Fig. 3), both of which are indications of stress. According to previous studies (Bondada et al., 2000; Ju et al, 2001), vegetable oils form a film that covers microcracks and stomata on leaf or fruit surfaces, thus inhibiting normal exchange of volatiles. This may lead to stress-induced, ethylene-mediated leaf abscission.

Our results also showed that late fall defoliation with VOE, followed by leaf removal from the orchard floor, was an effective way to control scab infection the following season. Without leaf removal, tree defoliation with VOE reduced but did not control scab. The reduction in scab pressure, however, makes possible a softer approach of disease control in early spring, such as early application of lime sulfur.

If the cost or availability of labor were of concern, another approach to scab control would be to eliminate the primary scab infection without removing leaves from the orchard floor. Furthermore, our results showed that VOE plus either lime sulfur or urea, or all three combined, defoliated trees in late fall and reduced scab infection the following season to a low level. Treatment with lime sulfur or urea has been used for scab control during the growing season. Urea at $5 \%$ was effective in reducing scab severity. In this trial, neither $2 \%$ lime sulfur nor $2 \%$ urea alone applied to trees before leaf fall was effective for scab control, but when combined with VOE both demonstrated positive synergistic control. Urea applied alone delayed leaf drop, which is undesirable for trees to overwinter safely. By adding VOE, however, urea-induced delay in leaf drop was almost eliminated. Although for certified organic fruit production the use of synthetic urea is not permitted, the combination of VOE with lime sulfur or urea or both could reduce labor in growing areas with high scab pressure and, therefore, play an important role in integrated and conventional fruit production. Since many diseases or insect pests overwinter in or on leaves, the impact of this practice on other pathogens also warrants further investigation.

A concern with tree defoliation is the subsequent effects on tree nutrition, vigor, and hardiness. In late fall, leaves start to remobilize nutrients to the subtending woody tissues. If the tree is defoliated too early, it is possible nutrient levels in the wood would be reduced, thereby affecting tree physiology. Early defoliation of nursery trees reduced nitrogen loss from leaves (Guak et al., 2001). According to our observation, however, VOE applied in October did not reduce tree hardiness, shoot growth, or tree vigor. In China, hand removal of certain leaves around fruit to improve fruit color has been practiced for many years and, according to our observations, removing $10 \%$ to $30 \%$ of the leaves on a tree 1 month before harvest in consecutive seasons did not significantly affect tree hardiness, vigor, return of bloom, or tree growth. The addition of urea to VOE treatment might also compensate for the loss of nitrogen from the leaves. Further study is needed to monitor the nutrient status of leaf and woody tissue during late fall to determine the optimum time for tree defoliation and scab control.

We observed that VOE applied to trees after harvest tended to delay anthesis between $2-5 \mathrm{~d}$, depending on concentration as well as on microclimate. Dormant sprays of soybean oil also delayed blossoming of peaches (Prunus persica) (Myers et al., 1996). In some humid areas such as Shandong province in China or the northeastern
U.S., freezing injury in early spring is often a concern for fruit growers, and a 4 to $5 \mathrm{~d}$ delay in blossoming might help protect young fruit buds from freezing injury. Nonetheless, whether the tendency for delayed bloom is caused by VOE itself or in part by treatment-induced defoliation requires further investigation. Delay of anthesis by VOE treatment may have other impacts on fruit production.

\section{Literature cited}

Bondada, B.R., C.E. Sams, D.E. Deyton, and J.C Cummins. 2000. Apple and peach leaf and stem surface morphology and soybean oil retention as influenced by stimulated rainfall and soybean oil emulsions. J. Amer. Soc. Hort. Sci. 125:553-557.

Biggs, A.R. 1990. Apple scab, p. 6-9 In: A.L. Jones and H.S. Aldwinckle (eds.). Compendium of apple and pear diseases. APS Press, St. Paul, Minn.

Carisse, O., V. Philion, D. Rolland, and J. Bernier. 2000. Effect of fall application of fungal antagonists on spring ascospore production of the apple scab pathogen, Venturia inaequalis. Phytopathology 90:31-37.

Guak, S., L. Cheng, and L. Fuchigami. 2001. Foliar urea pretreatment tempers inefficient $\mathrm{N}$ recovery resulting from copper chelate (CuEDTA) defoliation of apple nursery plants. J. Hort. Sci. Biotechnol. 76:35-39.

Ju, Z. and E.A. Curry. 2000. Stripped corn oil emulsion alters ripening, reduces superficial scald, and reduces core flush in 'Granny Smith' apples and decay in 'd'Anjou' pears. Postharvest Biol. Technol. 2:185-193.

Ju, Z., Y. Duan, and Z. Ju. 2000. Mono-, di-, and tri-acylglycerols and phospholipids from plant oils inhibit scald development in 'Delicious' apples. Postharvest Biol. Technol. 19:1-7.

Ju, Z., Y. Duan, Z. Ju, and A. Guo. 2001. Corn oil emulsion for early bloom thinning of trees of 'Delicious' apple, 'Feng Huang' peach, and 'Bing' cherry. J. Hort. Sci. Biotechnol. 76:327-331.

McArtney, S., J. Campbell, K. Foote, and H. Stiefel. 2000. Thinning options for organic apple production. Orchardist 73:34-35.

MacHardy, W.E. 1996. Apple scab. Amer. Phytopathol. Soc., St. Paul, Minn.

Myers, R.E., D.E. Deyton, and C. E. Sams. 1996. Applying soybean oil to dormant peach trees alters internal atmosphere, reduces respiration, delays bloom, and thins flower buds. J. Amer. Soc. Hort. Sci. 121:96-100.

Sutton, D.K., W.E. MacHardy, and W.G. Lord. 2000. Effects of shredding or treating apple leaf liter with urea on ascospore dose of Venturia inaequalis and disease buildup. Plant Dis. 84:1319-1326.

Vessen, P. and D. Gubler. 1995. North coast apple scab trials 1993/1994, Organic and conventional materials comparison. Plant Protection Quarterly 5:17. 